\title{
Hubungan Pengetahuan, Sikap dan Ketersediaan Sarana Prasarana dengan Perilaku Pengolahan Limbah Medis oleh Petugas Kebersihan
}

\author{
Galih Tri Puji Laksono ${ }^{1}$, Agustina Sari ${ }^{2}$ \\ 1,2Program Sarjana Kesehatan Masyarakat, Sekolah Tinggi Ilmu Kesehatan Indonesia Maju \\ Jln. Harapan Nomor 50, Lenteng Agung - Jakarta Selatan 12610, Telp: (021) 78894045 \\ Email: ${ }^{1}$ tripujigalih6847@gmail.com, ${ }^{2}$ agustinasari9882@gmail.com
}

Editor: -

Hak Cipta:

(C)2021 Artikel ini memiliki akses terbuka dan dapat didistribusikan berdasarkan ketentuan Lisensi Atribusi Creative Commons, yang memungkinkan penggunaan, distribusi, dan reproduksi yang tidak dibatasi dalam media apa pun, asalkan nama penulis dan sumber asli disertakan. Karya ini dilisensikan di bawah Lisensi Creative Commons Attribution Share Alike 4.0 Internasional.
A B S T R A C T

Introduction: The development of health service facilities is currently growing rapidly, but on the other hand, the waste produced is a threat in itself to environmental sustainability. Therefore, the health service unit has the obligation and responsibility to manage the waste produced, including in the hospital.

Objectives: The research objective was to determine the relationship between knowledge, attitudes and infrastructure towards the behavior of medical waste treatment by cleaners in the Thousand Islands Regional Hospital in 2020.

Method: The quantitative research method used a cross sectional design. The population of this study were all employees of the Seribu Kepuluan Regional General Hospital. The sampling technique used was purposive sampling with a total sample size of 106 people. The data used are primary data through distributing questionnaires and secondary data from books and literature. Data analysis was performed by univariate and bivariate with the chisquare test.

Result: The results showed the relationship between knowledge with ( $p$-value $=0,000$ and $O R=43,333)$, attitude with ( $p$-value = $0,000$ and $O R=12,692)$, and infrastructure ( $p$-value $=0,000$ and $O R=25,143$ ) on waste management behavior. medical by janitor. There is a relationship between knowledge, attitudes, and facilities and the behavior of medical waste management by cleaning workers.

Conclution: It is hoped that the Seribu Islands Regional General Hospital will provide training, and provide complete facilities and infrastructure in medical waste management in order to increase the knowledge of hospital staff and maximize medical waste management.

Keyword: Knowledge, Attitudes, and Infrastructure. 


\section{Pendahuluan}

Pembangunan sarana pelayanan kesehatan saat ini berkembang sangat pesat, sehingga dapat memberikan dampak yang positif dalam program peningkatan kesehatan masyarakat. Namun di sisi lain, limbah yang dihasilkan merupakan ancaman tersendiri bagi kelestarian lingkungan hidup dan bagi kesehatan masyarakat. Limbah rumah sakit dapat mencemari lingkungan penduduk di sekitar rumah sakit dan dapat menimbulkan masalah kesehatan. Hal ini dikarenakan sampah rumah sakit dapat mengandung berbagai jasad renik penyebab penyakit pada manusia. ${ }^{1}$ Unit-unit pelayanan kesehatan memiliki "kewajiban untuk memelihara" lingkungan dan kesehatan masyarakat, serta memiliki tanggung jawab khusus yang berkaitan dengan limbah yang dihasilkan termasuk rumah sakit. ${ }^{2}$

Berdasarkan data, Asian Devlopment Bank volume limbah medis di lima negara di Asia Tenggara yaitu Filipina (280 kg/hari), Indonesia (212 kg/hari), Malaysia (154 kg/hari), Thailand (210 kg/hari), Vietnam (160 kg/hari). ${ }^{3}$ Berdasarkan data Kementerian Kesehatan tahun 2020 terdapat 2.820 rumah sakit, 9.825 puskesmas, dan 7.641 klinik di Indonesia. Timbunan sampah medis bisa mencapai 296,86 ton per hari yang dihasilkan dari fasilitas pelayanan kesehatan yang tersebar di Indonesia. Sementara kapasitas pengolahan yang ada hanya 115,68 ton per hari. ${ }^{4}$ Dan Berdasarkan Asian Development Bank (ADB) memperkirakan untuk DKI Jakarta saja akan menghasilkan limbah medis 212 ton/hari. ${ }^{5}$

Pengolahan limbah dapat didefinisikan sebagai suatu tindakan yang dilakukan terhadap limbah mulai dari tahap pengumpulan di tempat sumber, pengangkutan, penyimpanan serta tahap pengolahan akhir yang berarti pembuangan atau pemusnahan. ${ }^{6}$ Faktor yang berhubungan dengan perilaku pengolahan limbah yaitu: Predisposing Factors yaitu faktor yang memudahkan atau mempredisposisi terjadinya perilaku seseorang, antara lain pengetahuan, sikap, kepercayaan, tradisi dan nilai. Reinforcing Factors yaitu faktor yang memberikan kebijakan, antara lain sikap dan prilaku petugas, peraturan dan Undang-undang. Sedangkan pada enabling faktor yang memungkinkan terlaksananya pembuangan sampah medis adalah tersedianya fasilitas misalnya sarung tangan, sepatu boot, dan kantong plastik. (7) Faktor pengetahuan menjadi dasar keberhasilan pengolahan limbah medis rumah sakit. Pengetahuan tentang pengolahan limbah harus dimiliki seorang Petugas Pengelola Limbah (PPL) sebagai tanggungjawab langsung kepada Direktur rumah sakit. Keberhasilan pengolahan sampah rumah sakit selain dilihat dari tingkat pengetahuan, ditentukan juga dari sikap. Sikap akan mempengaruhi perilaku petugas untuk berperilaku dengan baik dan benar dalam melakukan upaya penanganan dan pembuangan sampah. Dukungan pengetahuan dan sikap ini akan berpengaruh langsung terhadap perilaku yang nyata dalam mengelola limbah. Faktor ketersediaan sarana dan prasarana merupakan sesuatu yang dapat digunakan sebagai alat dalam mencapai sesuatu atau tujuan dan merupakan penunjang untuk terjadinya suatu proses untuk menuju kehendak yang ingin dicapai. ${ }^{8}$

Berdasarkan Studi Pendahuluan yang dilakukan di Rumah Sakit Daerah Kepulauan Seribu dengan mewawancarai petugas kebersihan di Rumah Sakit Daerah Kepulauan Seribu didapatkan bahwa 10 responden mengatakan bahwa sikap pengelolahan limbah medis merupakan tanggung jawab seluruh pegawai ini terbukti dengan kepatuhan sikap pegawai dalam mentaati peraturan Rumah Sakit Daerah dalam membuang limbah medis sesuai dengan kriterianya di dalam sarana prasarana yang telah disediakan, 10 responden mengatakan bahwa sarana prasarana yang tersedia di Rumah Sakit Daerah Kepulauan Seribu sudah memadai dalam pengelolaan limbah. Dan 7 dari 10 responden kurang mengetahui cara pengolahan limbah medis dengan baik dan benar. Hal tersebut dikarenakan masih banyaknya pegawai yang kurang edukasi terkait pengolahan medis seperti pemilihan limbah medis habis pakai. 


\section{Journal of

Berdasarkan latar belakang diatas, peneliti merasa tertarik melakukan penelitian yang berjudul "Hubungan Pengetahuan, Sikap dan Sarana Prasarana terhadap Perilaku Pengolahan Limbah Medis oleh Petugas Kebersihan di Lingkungan Rumah Sakit Daerah Kepulauan Seribu Tahun 2020”.

\section{Metode}

Jenis penelitian ini merupakan penelitian kuantitatif. Desain penelitian yang digunakan adalah cross-sectional (potong lintang), yaitu pengumpulan data penelitian yang dilaksanakan sekaligus pada suatu saat (point time approach.). ${ }^{9}$ Data variabel dependen dan variabel independen diambil dalam waktu yang bersamaan untuk mengetahui hubungan pengetahuan, sikap, dan sarana prasarana dengan perilaku pengolahan limbah medis oleh petugas kebersihan di Rumah Sakit Daerah Kepulauan Seribu Tahun 2020.

Populasi adalah keseluruhan subjek penelitian yang menyangkut masalah yang diteliti. ${ }^{10}$ Populasi dalam penelitian ini adalah seluruh pegawai Rumah Sakit Daerah Kepulauan Seribu sebanyak 143 orang. Teknik pengambilan sample menggunakan teknik purposive sampling. Purposive sampling adalah salah satu teknik sampling non random sampling dimana peneliti menentukan pengambilan sampel dengan cara menetapkan ciri-ciri khusus yang sesuai dengan tujuan penelitian sehingga diharapkan dapat menjawab permasalahan penelitian. ${ }^{11}$ Selama penelitian berlangsung pada tanggal 1517 Agustus 2020 sebanyak 106 responden. Syarat sampel harus memenuhi beberapa kriteria-kriteria, diantaranya: kriteria inklusi, dimana kriteria inklusi dalam penelitian ini yaitu Pegawai Rumah Sakit Daerah Kepulauan Seribu, responden yang bersedia mengisi ketersediaan menjadi responden; Kriteria non inklusi, kriteria non inklusi dalam penelitian ini yaitu bukan pegawai Rumah Sakit Daerah Kepulauan Seribu, dan tidak bersedia menjadi responden; kriteria ekslusi, kriteria eksklusi dalam penelitian ini yaitu pegawai Rumah Sakit Daerah Kepulauan Seribu yang datanya tidak lengkap dalam pengisian kuesioner.

Pengolahan data dilakukan dengan melakukan analisis univariat dan analisis bivariat. Analisis univariat digunakan untuk menggambarkan distribusi frekuensi variabel penelitian. Analisis bivariat digunakan untuk membuktikan ada tidaknya hubungan antar variabel bebas dengan variabel terikat dengan menggunakan uji chi-square.

Hasil dari analisis kemudian dibandingkan dengan beberapa teori yang berada dalam tinjauan pustaka dan hasil penelitian sebelumnya. Penyajian data hasil penelitian ini disajikan dalam bentuk teks dan tabel (tekstular dan tabular) berdasarkan variabel yang diteliti yang memberikan keterangan berbentuk angka dan teks tentang suatu data.

\section{Hasil}

\section{Analisis Univariat}

Tabel 1. Distribusi frekuensi responden berdasarkan variabel yang diteliti.

\begin{tabular}{llcc}
\hline \multicolumn{1}{c}{ Variabel } & \multicolumn{1}{c}{ Kategori } & n & \% \\
\hline Perilaku pengelolaan & Kurang baik & 46 & 43,4 \\
\hline & Baik & 60 & 56,6 \\
\hline Pengetahuan & Rendah & 48 & 45,3 \\
\hline & Tinggi & 58 & 54,7 \\
\hline Sikap & Kurang baik & 43 & 40,6 \\
\hline
\end{tabular}




\begin{tabular}{llll}
\hline & Baik & 63 & 59,4 \\
\hline Sarana Prasarana & Tidak Lengkap & 37 & 34,9 \\
\hline & Lengkap & 69 & 65,1 \\
\hline
\end{tabular}

Sumber : Data Olahan, 2020

Berdasarkan Hasil penelitian pada tabel diatas, menunjukan distribusi frekuensi responden diantaranya berdasarkan perilaku pengelolaan limbah medis diketahui bahwa responden yang kurang baik sebanyak 46 responden $(43,4 \%)$, dan responden yang berperilaku baik sebanyak 60 responden $(56,6 \%)$. berdasarkan pengetahuan responden diketahui bahwa responden yang memiliki pengetahuan rendah sebanyak 48 responden $(45,3 \%)$ dan responden yang memiliki pengetahuan tinggi sebanyak 58 responden (54,7\%). Berdasarkan sikap responden diketahui yang memiliki sikap yang kurang baik sebanyak 43 responden $(40,6 \%)$ dan responden yang memiliki sikap yang baik sebanyak 63 responden $(59,4 \%)$. Berdasarkan sarana prasarana, diketahui bahwa responden yang menyatakan sarana prasana yang dimiliki tidak lengkap sebanyak $37(34,9 \%)$ dan responden yang menyatakan memiliki sarana prasarana lengkap sebanyak $69(65,1 \%)$.

\section{Analisis Bivariat}

Berdasarkan tabel 2, menurut hasil analisis variabel pengetahuan diketahui bahwa perilaku petugas kebersihan dalam perilaku pengelolaan limbah medis diperoleh bahwa terdapat $52(49,1 \%)$ responden berpengetahuan tinggi mempunyai perilaku baik dan terdapat $40(37,7 \%)$ responden berpengetahuan rendah mempunyai perilaku yang kurang baik. Hasil uji statisik menggunakan uji chi square didapatkan nilai p-value $=0,000<\alpha 0,05$, maka dapat dikatakan ada hubungan antara pengetahuan dengan perilaku petugas kebersihan dalam perilaku pengelolaan limbah medis di Rumah Sakit Umum Daerah Kepulauan Seribu Tahun 2020. Hasil penelitian didapatkan juga nilai OR 43,333 (CI 95\%=13,915-134,943), yang dapat disimpulkan bahwa pengetahuan responden yang rendah berpeluang 43,333 kali berperilaku kurang baik dibandingkan dengan responden mempunyai pengetahuan yang tinggi. Hubungan ini menunjukkan bahwa semakin baik pengetahuan yang dimiliki petugas kebersihan maka semakin baik pula proses dalam berperilaku pengelolaan limbah medis.

Menurut hasil analisis variabel sikap diketahui bahwa perilaku petugas kebersihan dalam pengelolaan limbah medis diperoleh bahwa sebanyak $50(47,2 \%)$ responden bersikap baik mempunyai perilaku yang baik, sedangkan sebanyak $33(31,1 \%)$ responden bersikap kurang baik mempunyai perilaku yang kurang baik. Hasil uji statistik menggunakan uji chi square didapatkan nilai p-value $=0,000<0,05$, maka dapat disimpulkan terdapat hubungan antara sikap dengan perilaku. Hasil penelitian didapatkan juga nilai OR 12,692 (CI 95\% = 4,986-32,307), yang dapat disimpulkan bahwa sikap responden yang kurang baik berpeluang 12,692 kali berperilaku kurang baik dibandingkan dengan responden mempunyai sikap yang baik. Hubungan ini menunjukkan bahwa semakin baik sikap yang dimiliki petugas kebersihan maka semakin baik pula proses dalam berperilaku pengelolaan limbah medis.

Kemudian menurut hasil analisis variabel sarana dan prasarana diketahui bahwa perilaku petugas kebersihan dalam pembuangan sampah infeksius diperoleh data bahwa sebanyak $55(51,9 \%)$ sarana dan prasarana yang lengkap perilaku petugas kebersihan baik dalam pembuangan sampah infeksius, sedangkan sebanyak $32(30,2 \%)$ sarana dan prasarana tidak lengkap perilaku petugas kebersihan tidak lengkap dalam pembuangan sampah infeksius. Hasil uji statistik menggunakan uji chi square didapatkan nilai p-value $=0,000<0,05$, maka dapat disimpulkan terdapat hubungan antara sarana dan prasarana dengan perilaku. Hasil penelitian didapatkan juga nilai OR : 25, 143 (CI 95\%=8,284-76,309), 
yang dapat disimpulkan bahwa sarana dan prasarana rumah sakit yang kurang baik berpeluang 25,143 kali responden berperilaku kurang baik dibandingkan dengan sarana dan prasarana rumah sakit yang lengkap. Hubungan ini menunjukkan bahwa semakin lengkap sarana prasarana yang dimiliki petugas kebersihan maka semakin baik pula proses dalam berperilaku pengelolaan limbah medis.

Tabel 2. Hasil analisis bivariat

\begin{tabular}{|c|c|c|c|c|c|c|c|}
\hline \multirow{3}{*}{ Variabel } & \multirow{3}{*}{ Kategori } & \multicolumn{4}{|c|}{ Perilaku Pengelolaan } & \multirow{3}{*}{ P-Value } & \multirow{3}{*}{ OR } \\
\hline & & \multicolumn{2}{|c|}{ Kurang Baik } & \multicolumn{2}{|c|}{ Baik } & & \\
\hline & & $\mathrm{n}$ & $\%$ & $\mathrm{~N}$ & $\%$ & & \\
\hline \multirow{2}{*}{ Pengetahuan } & Rendah & 40 & 37,7 & 8 & 7,5 & \multirow{2}{*}{0,000} & \multirow{2}{*}{43,333} \\
\hline & Tinggi & 6 & 49,1 & 52 & 49,1 & & \\
\hline \multirow{2}{*}{ Sikap } & Kurang Baik & 33 & 31,1 & 10 & 9,4 & \multirow{2}{*}{0,000} & \multirow{2}{*}{12,692} \\
\hline & Baik & 13 & 12,3 & 50 & 47,2 & & \\
\hline \multirow{2}{*}{$\begin{array}{l}\text { Sarana } \\
\text { Prasarana }\end{array}$} & Tidak Lengkap & 32 & 30,2 & 5 & 4,7 & \multirow{2}{*}{0,000} & \multirow{2}{*}{25,143} \\
\hline & Lengkap & 14 & 13,2 & 55 & 51,9 & & \\
\hline
\end{tabular}

Sumber : Data Olahan, 2020

\section{Pembahasan}

\section{Hubungan Pengetahuan Dengan Perilaku Petugas Kebersihan Terhadap Perilaku Pengelolaan Limbah Medis di RSUD Kepulauan Seribu}

Berdasarkan hasil penelitian, pengetahuan dengan perilaku petugas kebersihan terhadap perilaku pengelolaan limbah medis di RSUD Kepulauan Seribu tahun 2020 dengan nilai p-value $=0,000 \leq 0,05$. Hasil penelitian ini sesuai dengan yang dikemukakan oleh Ngurah Pradnyana dan Mahayana, bahwa terdapat hubungan antara pengetahuan dengan perilaku perawat dalam pengelolaan sampah medis di Rumah Sakit Daerah Mangusada Kabupaten Badung. Tingkat pengetahuan erat kaitannya dengan pendidikan semakin tinggi tingkat pendidikan maka tingkat pengetahuan perawat juga akan semakin baik dalam perilaku pengelolaan limbah medis. ${ }^{12}$

Pernyataan tersebut juga didukung oleh hasil penelitian yang dilakukan oleh Annisa Fitri Maharani,dkk yang menyatakan ada hubungan pengetahuan dan sikap terhadap pengelolaan limbah medis. Menyatakan bahwa faktor pengetahuan menjadi dasar keberhasilan pengelolaan sampah rumah sakit.Pengetahuan tentang pengelolaan sampah atau limbah harus dimiliki seorang Petugas Pengelola Limbah (PPL) sebagai tanggung jawab langsung kepada Direktur rumah sakit. Ia harus bekerja sama dengan petugas pengontrol infeksi, kepala bagian farmasi, dan teknisi radiologi agar memahami prosedur yang benar di dalam penanganan dan pembuangan limbah patologi, farmasi, kimia dan limbah radioaktif. ${ }^{13}$

Faktor pengetahuan dan sikap merupakan faktor domain terjadinya perilaku maka upaya adanya pelatihan, pengawasan, peneguran maupun menyediakan sarana prasarana dalam hal ini menambah jumlah tempat sampah merupakan beberapa upaya untuk memperbaiki perilaku perawat dalam mengelola limbah medis. ${ }^{12}$ Selain itu, menurut Mubarak mengatakan bahwa pekerjaan dan umur adalah dua hal yang mempengaruhi tingkat pengetahuan individu. Maka dapat disimpulkan bahwa semakin tinggi tingkat pendidikan, lama bekerja, dan usia mempengaruhi tingkat pengetahuan individu dalam perkembangan sikap khususnya terkait dalam pengelolaan limbah medis. ${ }^{14}$ 


\section{Journal of

Menurut asumsi peneliti bahwa pengetahuan petugas kebersihan merupakan salah satu faktor predisposisi suatu perilaku. Pengetahuan petugas kebersihan dapat terus meningkat apabila pihak rumah sakit dapat terus meningkatkan kemampuan petugas kebersihan dengan mengadakan berbagai pelatihan tidak hanya kepada petugas kebersihan melainkan pula pada semua karyawan pada aspek pengelolaan sampah medis di RSUD Kepulauan Seribu.

\section{Hubungan Sikap dengan Perilaku Petugas Kebersihan terhadap Perilaku Pengelolaan Limbah Medis di RSUD Kepulauan Seribu}

Berdasarkan hasil penelitian, sikap dengan perilaku petugas kebersihan terhadap perilaku pengelolaan limbah medis di RSUD Kepulauan Seribu tahun 2020 dengan nilai p-value $=0,000 \leq 0,05$. Hasil penelitian ini sesuai dengan yang dikemukakan oleh Ngurah Pradnyana dan Mahayana yang menyatakan bahwa sikap individu berpengaruh terhadap perilaku pengelolaan limbah medis. individu yang bekerja di Rumah Sakit dan yang berkontak langsung dengan limbah medis dan penghasil limbah medis seharusnya memiliki pengetahuan dan sikap yang baik tentang pengelolaan limbah medis padat agar menjadi pencegah dari terjadinya risiko yang memungkinkan terjadi akibat limbah medis padat. ${ }^{12}$

Pernyataan tersebut didukung oleh penelitian yang dilakukan oleh Nursamsi, dkk dengan nilai pvalue $0,001<0,05$ yang menyatakan adanya hubungan antara sikap dengan pengelolaan limbah medis padat puskesmas di Kabupaten Siak. Sikap mempengaruhi proses pengolahan limbah medis padat selanjutnya pengetahuan merupakan faktor penentu keberhasilan pengelolaan limbah medis padat. ${ }^{15}$ Sikap merupakan sarana pencapaian tujuan, orang memandang sebagaimana objek sikap dapat digunakan sebagai sarana atau alat dalam rangka pencapaian tujuannya, maka orang akan bersikap positif terhadap objek tersebut. Hal ini juga disebut sebagai fungsi penyesuaian karena sikap yang diambil seseorang akan dapat menyesuaikan diri secara baik terhadap sekitarnya. ${ }^{16}$

Rumah sakit sebagai penghasil limbah medis padat dan memiliki risiko yang besar terhadap kecelakaan dan penyebaran penyakit khusunya bagi individu yang bekerja di instansi kesehatan tersebut sehingga sebagai individu yang bekerja di Rumah Sakit dan yang berkontak langsung dengan limbah medis dan penghasil limbah medis seharusnya memiliki pengetahuan dan sikap yang baik tentang pengelolaan limbah medis padat agar menjadi pencegah dari terjadinya risiko yang memungkinkan terjadi akibat limbah medis padat. ${ }^{10}$ Sikap responden yang baik akan berhubungan dengan tindakan dalam upaya pengelolaan limbah medis karena dinilai responden memahami betul pengetahuan tentang pengelolaan limbah medis. ${ }^{17}$

Menurut asumsi peneliti, bahwa sikap yang tidak baik dan kurangnya rasa tanggung jawab petugas kebersihan terhadap pengelolaan limbah medis dan non medis pada setiap ruangan akan mengakibatkan infeksi nosokomial, jika peran dan tanggung jawab petugas kebersihan dapat diterapkan dengan seksama, konsisten dan menyeluruh sehingga dapat menggugah kesadaran terhadap permasalahan kesehatan dan keselamatan lingkungan mengingat bahaya yang ditimbulkan oleh limbah medis dan non medis tersebut jika tidak dikelola dengan baik dan benar.

\section{Hubungan Sarana Prasarana dengan Perilaku Petugas Kebersihan terhadap Perilaku Pengelolaan Limbah Medis di RSUD Kepulauan Seribu}

Berdasarkan hasil penelitian, sarana prasarana dengan perilaku petugas kebersihan terhadap perilaku pengelolaan limbah medis di RSUD Kepulauan Seribu tahun 2020 dengan nilai p-value $=0,000$ $\leq 0,05$. Hasil penelitian ini sesuai dengan penelitian yang dilakukan oleh Nursamsi,dkk yang menyatakan bahwa adanya hubungan antara sarana prasarana dengan pengelolaan limbah medis padat 
puskesmas di Kabupaten Siak. Sarana prasarana yang memadai mempengaruhi proses pengolahan limbah medis padat. ${ }^{15}$

Penelitian tersebut didukung oleh penelitian Indah Nurhidayah dengan nilai p-value $0,014<0,05$ yang menyatakan adanya hubungan antara fasilitas dengan pengelolaan limbah medis padat puskesmas di RS Bhakti Wira Tamtama Semarang. Penyediaan kelengkapan fasilitas perlu menjadi perhatian karena menjadi salah satu faktor yang mempengaruhi proses pengolahan limbah medis padat. ${ }^{18}$ Pengolahan limbah medis yang baik dipengaruhi oleh banyak faktor seperti pengetahuan kesehatan lingkungan, sikap, dan sarana prasarana dalam upaya mewujudkan pengolahan limbah medis yang baik sehingga terciptannya kesehatan yang lebih baik. Faktor ketersediaan sarana dan prasarana merupakan sesuatu yang dapat digunakan sebagai alat dalam mencapai sesuatu atau tujuan dan merupakan penunjang untuk terjadinya suatu proses untuk menuju kehendak yang ingin dicapai. Fasilitas atau sarana merupakan segala hal yang memudahkan kelancaran tugas, segala jenis peralatan perlengkapan kerja lain yang berfungsi sebagai alat utama atau pembantu dalam pelaksanaan pekerjaan. Kelengkapan fasilitas sangat mempengaruhi beban kerja dalam melaksanakan tugas dan tanggung jawab seseorang. ${ }^{19}$ Penyediaan fasilitas tentu menjadi tanggung jawab pihak rumah sakit sehingga diperlukan perhatian dan pengawasan pihak manajemen khususnya dalam pengelolaan limbah medis. Selain itu, kepada petugas pengumpul sampah limbah medis agar tetap komitmen dalam menjaga dan menggunakan fasilitas penunjang pekerjaan yang telah disediakan oleh pihak rumah sakit. ${ }^{20}$

Menurut asumsi peneliti, bahwa dengan dimilikinya kesadaran oleh Rumah Sakit dalam menyediakan fasilitas kesehatan yang lengkap khusunya dalam pengelolaan limbah medis dapat meningkatkan perilaku petugas kebersihan dalam pengelolaan limbah medis, adapun kesadaran ini tidak akan terbentuk dan tidak akan berhasil merubah sikap petugas kebersihan apabila tidak ditunjang dengan penyediaan sarana prasarana yang tidak lengkap dalam pengelolaan limbah medis seperti belum tersedianya kapal limbah medis dalam proses pengiriman limbah medis dan TPS limbah medis yang tidak mencukupi dalam menampung limbah medis dalam ukuran cukup besar. Sarana prasarana tersebut sebagai salah satu fasilitas kesehatan dalam mencegah penularan infeksi di rumah sakit.

\section{Kesimpulan}

Berdasarkan hasil penelitian diperoleh kesimpulan perilaku petugas kebersihan di RSUD Kepulauan Seribu memiliki tingkat pengetahuan yang baik, sikap yang baik dan sarana prasarana yang lengkap sehingga membuat perilaku pengelolaan limbah medis di RSUD Kepulauan Seribu sudah baik. Faktor pengetahuan, sikap dan sarana prasarana memiliki hubungan terhadap perilaku pengelolaan limbah medis, dimana pengetahuan menjadi faktor yang paling berhubungan terhadap perilaku pengelolaan limbah medis.

Diharapkan pihak rumah sakit dapat lebih sering melakukan/ melaksanakan pelatihan tentang pengelolaan limbah medis dan non medis agar dapat meningkatkan perilaku tenaga kesehatan dalam pembuangan sampah infeksius dan memberikan sarana dan prasarana yang maksimal agar lebih terdukungnya perilaku pengelolaan yang semakin baik.

\section{Konflik Kepentingan}

Ucapan Terima Kasih 


\section{Journal of

\section{Pendanaan}

\section{References}

1. Chandra B. Pengantar KesehatanLingkungan. Jakarta: Kedokteran EGC; 2012.

2. Wahyu Widayati. Hubungan Antara Pengetahuan Dan Sikap Dengan Tindakan Petugas Kesehatan Dalam Upaya Pengelolaan Sampah Medis Di Rumah Sakit Griya Husada Madiun Tahun 2017, Stikes Bhakti Husada Mulia Madiun. 2017.

3. Asian Devlopment Bank. Stability Of SarsCov-2 In Different Environmental Conditions. 2020.

4. Kementerian Kesehatan. Laporan Kinerja Ditjen Kesehatan Masyarakat. 2020.

5. Teddy Prasetiawan. Permasalahan Limbah Medis Covid-19 Di Indonesia. 2020;XII(9).

6. Dionisus. Pengelolaan Limbah Medis Padat Di Puskesmas Borong Kabupaten Manggarai Nusa Tenggara Timur Provinsi Nusa Tenggara Timur. Universitas Brawijaya. 2015.

7. Notoatmodjo, S. Ilmu Perilaku Kesehatan. Jakarta: PT. Rineka Cipta, 2014.

8. Donsu. Filsafat ilmu. Assignment paper of filosophy. universitas gajah mada; 2017.

9. Notoatmodjo S. Promosi Kesehatan dan Perilaku Kesehatan. Jakarta: PT. Rineka Cipta.; 2012.

10. Sugiyono. Metode Penelitian Pendidikan Pendekatan Kuantitatif, Kualitatif, dan R\&D. bandung: alfabeta; 2016.

11. Sugiyono. Metode Penelitian Kuantitatif Kualitatif Dan R\&D. Bandung: Alfabeta; 2016.

12. Ngurah IG, Pradnyana G, Mahayana IMB. Hubungan pengetahuan dan sikap dengan perilaku perawat dalam pengelolaan sampah medis di rumah sakit daerah mangusada kabupaten badung. 2020;10(2):72-8.

13. Annisa Fitri Maharani, Irvan Afrandi, Titing Nurhayati. Pengetahuan dan Sikap Tenaga Kesehatan Terhadap Pengelolaan Limbah Medis Padat pada Salah Satu Rumah Sakit di Kota Bandung. Ilmu Kesehat Masyrakat. 2017;3(2).

14. Mubarak. Ilmu Kesehatan Masyarakat. Jakarta: Salemba Medika; 2012.

15. Nursamsi N, Thamrin T, Efizon D. Analisis Pengelolaan Limbah Medis Padat Puskesmas Di Kabupaten Siak. Din Lingkung Indones. 2017;4(2):86.

16. Yunita intan subagyo. hubungan pengetahuan, sikap dan sarana prasarana terhadap perilaku tenaga kesehatan dalam pengelolaan limbah medis padat di rumah sakit grha permata ibu depok tahun 2017. sekolah tinggi ilmu kesehatan indonesia maju; 2017.

17. Fauzi Kariki Tyas Suseno. Hubungan Pengetahuan, Sikap, Dan Sarana Prasarana Dalam Perilaku Pembuangan Sampah Infeksius Di Rsia Juliana Tajur Tahun 2016. Sekolah Tinggi Ilmu Kesehatan Indonesia Maju; 2016.

18. Indah Nurhidayah. Hubungan Pengetahuan, Sikap, dan Ketersediaan Fasilitas dengan Perilaku Perawat dalam Membuang Limbah Medis Padat di RS Bhakti Wira Tamtama Semarang Tahun 2015. 2015;

19. Nurali. No Title. Pengelolaan Limbah B3 Medis dan Sampah Terkontaminasi Covid-19”. 2020;

20. Purba ES, Khairunnisa C. Hubungan Pengetahuan, Sikap Dan Ketersediaan Fasilitas Dengan Praktik Petugas Pengumpul Limbah Medis Di Rumah Sakit Umum Cut Meutia Kabupaten Aceh Utara Tahun 2015. AVERROUS J Kedokt dan Kesehat Malikussaleh. 2018;1(2):23. 